Dept. of Food Hygiene,

Animal Health Research Institute, Assiut, Regional Laboratory

\title{
DETECTION OF AFLATOXINS RELEASED BY SOME ASPERGILLUS SPECIES ISOLATED FROM PROCESSED CHEESE TOGETHER WITH SOME AEROBIC AND ANAEROBIC SPORE FORMER ORGANISMS
}

(With 4 Tables)

By

NAHED M. WAHBA and EMAN KORASHY AHMED

(Received at18/11/2008)

الكشف عن السموم الفطرية المفرزة من بعض أنواع الأسبريجيلس المعزولة

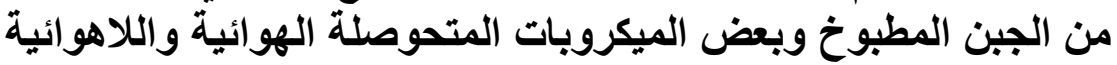

\section{ناهد محمد وهبه ، إبيمان قرشسى أحمد}

فى السنوات الأخيرة زاد الإقبال على استهلاك الجبن المطبوخ وذلك لقناعة المستهلك بسلامة

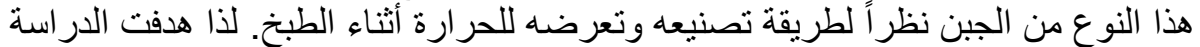

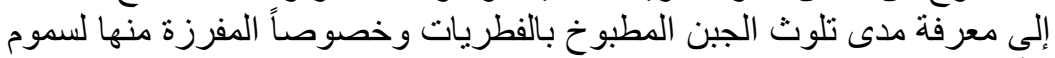
الأفلاتوكسين وكذلك تو اجد الميكروبات المتحوصلة الهو ائية و اللاهو ائية. لذا تم تحليل 120

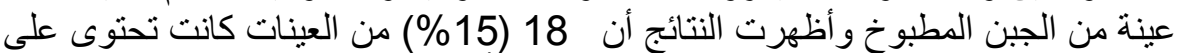
فطريات وخمائر وكان العدد الكلى لها

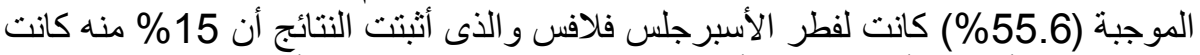

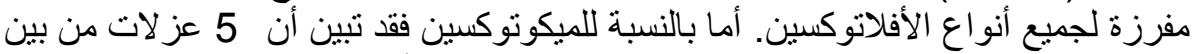

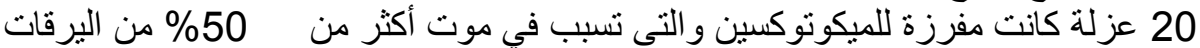
المختبرة ـ و نتاولت الدر اسة أيضاً تو اجد الميكروبات المتئن المتحوصلة الهو ائية و اللاهو ائية وقد

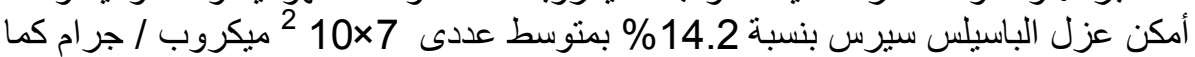
أمكن عزل كل من الباسيلس ماسيرنس ، الباسيلس ليشنيفورم و الباسيلس ميجاتيرم بالنسب الآتية 6.7 ، 16.7 ، 11.7 \% على التو الي، وكذلك الكلوستردينم بيرفنجنز بنسبة 13.3 من العينات المفحوصة. ولقد خلصت الدراسة إلى ضرورة إنى إتباع بعض الخطو ات الإنتاج جبن

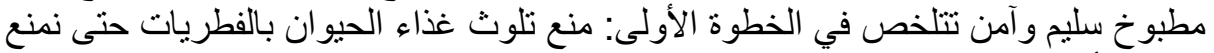

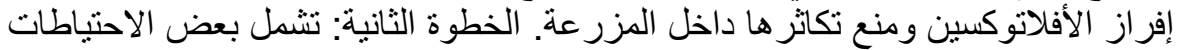

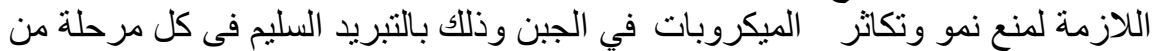
مر احل التصنيع وحتى يصل إلى المستهـلك. 
Processed cheese has an excellent history of safety; however, it is difficult to eliminate completely fungi and bacterial growth, activity and toxin production that threaten consumer's health. Methods: 120 processed cheese samples were analyzed for determination of total fungi and yeast count, as well as identification of the isolated fungi. Toxicity and aflatoxin produced by the isolated Asp. flavus using thin layer chromatographic technique. Bacillus species and $C$. perfringens count as spore former organisms. Results: Fungi and yeasts were present in $18(15 \%)$ of processed cheese samples with total count of $2.7 \times 10^{4} / \mathrm{g}$. Asp. flavus was the first prevalent species $(55.6 \%)$ of the positive samples. $5(25 \%)$ out of 20 isolates of Asp. flavus proved to produce mycotoxins, three of them were able to produce all types of aflatoxins. Mycotoxins producing isolates cause more than 50\% mortality of the larvae tested. Some aerobic and anaerobic sporeformers were isolated and counted. B. cereus was isolated from $17(14.2 \%)$ of processed cheese samples with an average count of $7 \times 10^{2} / \mathrm{g}$. B. macerans, B. lechniformis and B. megaterium were detected in 8 (6.7\%), $20(16.7 \%)$ and $14(11.7 \%)$ of samples, respectively. Moreover, C. perfringens was present in 16 (13.3\%) of samples. Conclusion: Two important points must be regarded to safe production of processed cheese; first one: is the measures to minimize the presence of spores. The second is to prevent spore germination and vegetative proliferation by adequate cooling during all steps of production till dispensation to the consumers.

Key words: Processed cheese, Aspergillus ssp., aflatoxins

\section{INTRODUCTION}

Processed cheese has an excellent history of safety. Production and consumption of processed cheese increased steadily. Today, large tons of natural cheeses are converted to processed cheese, the global production of processed cheese products is estimated at $\sim 1.5-1.8$ million ton/year (Guinee, 2003). Heat processing, packaging and cheese composition normally limit bacterial growth however, it is difficult to eliminate completely bacterial growth and activity in this type of cheese (Hamed et al., 1997). Airborne mold spores tend to grow on cheese where pockets of air exist between the packaging material and cheese surface (Hocking and Faedo, 1992). 
Aflatoxins (Afs) are hepatotoxic, mutagenic, carcinogenic and immuno suppressive toxins (Bennett and Klich, 2003 and Honikel, 2003). They are secondary metabolites produced by many strains of Aspergillus flavus and Asp. parasiticus. The major aflatoxins of concern are designated $A f B_{1}, B_{2}, G_{1}, G_{2}$ and $M_{1}$. Af $B_{1}$ is predominant in amount and toxicity (Mountney and Gould, 1988). Outbreaks of mycotoxicosis from Af $\mathrm{B}_{1}$ have been reported (Peraica et al., 1999). Cattle consume Af $B_{1}$ in feedstuff and transform it into Af $M_{1}$ so, milk and milk products can serve as indirect source of aflatoxins (Kisza and Domagala, 1994). Af $\mathrm{B}_{1}$ and $\mathrm{M}_{1}$ are highly toxic compound and its occurrence poses a threat to the health of consumers specially young children (Pierides et al., 2000).

Furthermore, aflatoxins are relatively stable compounds, not destroyed by processing and may even be concentrated. Their thermal stability disqualifies pasteurization and ultra pasteurization as methods of control (Carvajal et al., 2003 and Honikel, 2003).

Endo spore forming species of Bacillus and Clostridia are of great concern to the dairy industry causing both food spoilage and food poisoning. B. cereus and related species cause problems to the dairy industry by deteriorating the product (Eneroth et al., 2001) and by endangering people's health up consuming contaminated food (Ghelardi et al., 2002). B. cereus is considered to be the most important species however, more recently attention has been drawn to other species of bacillus that may occur in milk products more often and in higher concentrations than B. cereus (Mansour et al., 1999).

Likewise, $C$. perfringens is a classical agent of foodborne disease characterized by mildness and self limiting nature (Sanz et al., 2002). C. perfringens type A is considered the third leading cause of foodborne disease in the USA (Bos et al., 2005). Species of clostridia producing butyric acid like $C$. butyricum, C. perfringens and $C$. tertium cause sever defects in cheese as a consequence of late blowing or butyric blowing (Galle le Bourhis et al., 2005).

Therefore, and due to the dangerous role of molds in cheese, prevalence and count of mold are considered as standard test for checking the general sanitary measures adopted, together with toxin production and toxicity of Asp. flavus isolates. Moreover, the incidence and count of Bacillus species and $C$. perfringens are essential.

\section{MATERIALS and METHODS}


A total of 120 samples of processed cheese were collected and subjected to the following:

1- Preparation of the samples according to APHA (1992).

2- Enumeration and Isolation of molds and yeasts were done as described by Oxoid (1990).

3- Identification of isolated fungi was done in the Mycological Center, Fac. of Science, Assiut Univ.

4- Cultivation and extraction of the fungal toxins:

Asp. flavus isolates were collected and cultivated on Czapek's liquid medium fortified by $0.2 \%$ yeast extract and $1 \%$ peptone, incubated at $28^{\circ} \mathrm{C}$ for 10 days. The content of each flask (medium and mycelium) were homogenized for $5 \mathrm{~min}$. in high speed blender (1600 rpm) with $100 \mathrm{ml}$ chloroform. The extract procedure was repeated 3 times, washed with equal volume of dist. water, dried over anhydrous sodium sulfate, filtered then, concentrated under vacuum to near dryness and diluted to $1 \mathrm{ml}$ with chloroform.

5- Thin-layer chromatographic separation of mycotoxins:

Thin-layer chromatographic technique was used for qualitative identification of mycotoxins by comparison with appropriate reference standards (Gimeno, 1979 and Van Egmond et al., 1980).

6- Bioassay method for mycotoxins:

The immature brine shrimp (Artemia salina L.) was used for detection of aflatoxins and for other mycotoxins toxicity as described by Scott et al. (1980).

7- Enumeration, isolation and identification of Bacillus spp. using Mannitol egg yolk polymyxin agar (MYP) according to Lancette and Harmon (1980) and Cowan and Steel (1974).

8- Enumeration of $C$. Perfringens using lactose sulphite broth (Beerens et al., 1982) by applying most probable number (MPN) technique.

\section{RESULTS}

The results were manifested and tabulated in Tables (1-4).

Table 1: Incidence and count of different molds and yeasts isolated from processed cheese samples. 
Assiut Vet. Med. J. Vol. 55 No. 120 January 2009

\begin{tabular}{|l|c|c|c|c|}
\hline \multicolumn{1}{|c|}{ Mycoflora } & $\begin{array}{c}\text { No. of } \\
+\mathrm{ve} \\
\text { samples }\end{array}$ & $\begin{array}{c}\text { Frequency } \\
\%\end{array}$ & Total & Range \\
\hline Genera and species & No/18 & & & \\
Asp. flavipes & 1 & 5.6 & 100 & 100 \\
Asp. flavus & 10 & 55.6 & 3800 & $100-1400$ \\
Asp. fumigatus & 1 & 5.6 & 2000 & 2000 \\
Asp. niger & 8 & 44.4 & 1500 & $100-300$ \\
Asp. ochraceus & 1 & 5.6 & 100 & 100 \\
Asp. terrus & 1 & 5.6 & 6000 & 6000 \\
Asp. versicolor & 1 & 5.6 & 100 & 100 \\
Cochliobolus lunatus & 2 & 11.1 & 300 & $100-200$ \\
Cochliobolus spicifer & 1 & 5.6 & 100 & 100 \\
Emericella quadrilineata & 7 & 38.9 & 1800 & $100-500$ \\
Fusarium verticillioides & 4 & 22.2 & 500 & $100-200$ \\
Mucor hiemalis & 1 & 5.6 & 200 & 200 \\
Paecilomyces roseolus & 1 & 5.6 & 100 & 100 \\
Penicillium citrinum & 1 & 5.6 & 100 & 100 \\
Penicillium funiculocum & 3 & 16.6 & 300 & 100 \\
Penicillium purpurogenum & 2 & 11.1 & 200 & 100 \\
Rhizopus stolonifer & 2 & 11.1 & 200 & 100 \\
Yeasts & 5 & 27.7 & 9700 & $100-5000$ \\
Total mold and yeast count & $18 / 120$ & 15 & $2.7 \times 10^{4}$ & $100-6000$ \\
\hline
\end{tabular}

Table 2: Aflatoxin production and toxicity of Asp. flavus isolated from processed cheese samples.

\begin{tabular}{|c|c|c|c|c|c|c|c|c|c|}
\hline \multirow{2}{*}{$\begin{array}{c}\text { No. of } \\
\text { tested } \\
\text { isolates }\end{array}$} & \multicolumn{4}{|c|}{ Asp. flavus isolates producing } & \multicolumn{4}{c|}{ Toxicity test } \\
\cline { 2 - 10 } & Mycotoxins & \multicolumn{4}{|c|}{ Aflatoxins } & \multicolumn{2}{|c|}{ A } & \multicolumn{2}{c|}{$\mathrm{B}$} \\
\cline { 2 - 10 } & No. & $\%$ & No. & $\%$ & Types & No. & $\%$ & No. & $\%$ \\
\hline 20 & 5 & 25 & 3 & 15 & $\mathrm{~B}_{1}, \mathrm{~B}_{2}, \mathrm{G}_{1}, \mathrm{G}_{2}$ and $\mathrm{M}_{1}$ & 5 & 25 & 15 & 75 \\
\hline
\end{tabular}

A: indicates more than $50 \%$ mortality of larvae tested.

B: indicates less than $50 \%$ mortality of larvae tested.

Table 3: Incidence and count of some aerobic spore former organisms in processed cheese samples. 


\begin{tabular}{|l|c|c|c|c|c|}
\hline \multirow{2}{*}{\begin{tabular}{c}
\multirow{2}{*}{$\begin{array}{c}\text { Isolated } \\
\text { organisms }\end{array}$} \\
\cline { 5 - 6 }
\end{tabular}} & \multicolumn{2}{|c|}{ Positive samples } & \multicolumn{3}{|c|}{ Count /g } \\
\cline { 2 - 3 } & No./120 & $\%$ & Min. & Max. & Average \\
\hline B. cereus & 17 & 14.2 & $1 \times 10^{2}$ & $3.8 \times 10^{4}$ & $7 \times 10^{2}$ \\
B. macerans & 8 & 6.7 & $1 \times 10^{2}$ & $5 \times 10^{3}$ & $2 \times 10^{2}$ \\
B. lechniformis & 20 & 16.7 & $1 \times 10^{2}$ & $7 \times 10^{3}$ & $3 \times 10^{2}$ \\
B. megaterium & 14 & 11.7 & $2 \times 10^{2}$ & $7 \times 10^{3}$ & $3 \times 10^{2}$ \\
\hline
\end{tabular}

Table 4: Incidence, count and frequency distribution of $C$. perfringens in processed cheese samples.

\begin{tabular}{|c|c|c|c|c|c|}
\hline \multirow{2}{*}{$\begin{array}{c}\text { No. of samples } \\
\text { examined }\end{array}$} & \multicolumn{2}{|c|}{ Positive samples } & \multicolumn{3}{c|}{ MPN/g } \\
\cline { 2 - 6 } & No. & $\%$ & $3-20$ & $20-70$ & $70-1100$ \\
\hline 120 & 16 & 13.3 & 15 & - & 1 \\
\hline
\end{tabular}

\section{DISCUSSION}

Consumer demand for processed food challenges the food industry to produce tasty-nutritious and microbially safe products (Leistner and Gorris, 1995). Mycobiota growing in food is often beneficial for the ripening and development of specific flavor characteristics of the product, but it can be harmful due to the production of mycotoxins (Federico et al., 2002).

Mold and yeasts were present in $18(15 \%)$ of processed cheese samples with total count of $2.7 \times 10^{4}$ (Table 1). Higher incidence and count were reported by Wafy (2006) and Amin (2007). 100\% incidence was detected by Ismail and Sabreen (2001) and Sabreen and Zaky (2001). On the other hand, no molds could be isolated from processed cheese examined by Taniwaki and Dender (1992). Processed cheese may serve as a substrate to Asp. flavus and other mycotoxins producing fungi (Sabreen and Zaky, 2001 and Amin, 2007).

Asp. flavus was the first prevalent species encountered in processed cheese samples. It was found in $10(55.6 \%)$ of the positive samples in counts ranged from 100-1400 cells/g, other species were isolated in different percentages and counts (Table 1). The considerable high incidence and count of Asp. flavus is of great importance for its production of Aflatoxins. Several researches detected aflatoxins in 
processed cheese (Sabreen and Zaky, 2001; Sarimehmetoglu et al., 2004 and Yaroglu et al., 2005). Af $\mathrm{B}_{1}$ and $\mathrm{M}_{1}$ are highly toxic compound and its occurrence poses a threat to the health of consumers specially young children (Pierides et al., 2000).

In the present study, 5(25\%) out of 20 isolates of Asp. flavus proved to produce mycotoxins, three of them were able to produce all types of aflatoxins $\left(B_{1}, B_{2}, G_{1}, G_{2}\right.$ and $\left.M_{1}\right)$. All mycotoxins producing isolates ( 5 isolates) cause more than $50 \%$ mortality of the larvae tested (Table 2). The mycotoxin production and toxicity by Asp. flavus wes previously studied by El-Maraghy and Zohri (1988) and Abdel-Malek et al. (1993).

Because mycotoxins are natural contaminants of food and their exposure is more likely to occur in world where poor methods of food handling and storage are common, their formation is unavoidable and methods of controlling are usually preventive.

Aerobic spore formers like Bacillus species naturally existed in numerous foods owing to their wide distribution in the environment. Growth of $B$. cereus often limits the shelf life of dairy products kept at refrigerator temperatures, if conditions are right, they multiply rapidly and produce sufficient toxins to induce symptoms of food poisoning (Borge et al., 2001 and Vissers et al., 2007).

$B$. cereus was previously isolated from processed cheese by Wahba (1997); Sabry (2001) and Abdel-Hameed (2004). In this work, B. cereus was isolated from $17(14.2 \%)$ of processed cheese samples with counts ranged from $1 \times 10^{2}$ to $3.8 \times 10^{4}$, with the average count was $7 \times 10^{2}$ organisms/g (Table 3 ). Concentration of $<10^{3} / \mathrm{g}$ may considered innocuous since the minimal level required to cause illness has been estimated to be $>10^{5} / \mathrm{g}$ (ICMSF, 1996).

$B$. macerans, B. lechniformis and B. megaterium were detected in $8(6.7 \%), 20(16.7 \%)$ and $14(11.7 \%)$ of samples, respectively (Table $3)$. Although some foodborne gastroenteritis incidents attributed to $B$. lechniformis have been reported (Turnbull, 1997 and Salkinoja-Salonen et al., 1999), B. lechniformis secreted protease enzyme which produce milk curds and may be useful as a new source of milk coagulants for cheese making industry (Ageitos et al., 2007).

The clostridium species present in cheese originate from milk which is contaminated by these spores during milking, even $>0.2$ clostridium spores $/ \mathrm{ml}$ in raw milk can affect the cheese during processing (Kalzendorf, 1995). 
C. perfringes was present in $16(13.3 \%)$ of processed cheese samples. Most of samples lines within the range of 3-20 cfu/g (Table 4). Lower incidences of $C$. perfringens and other anaerobic organisms were observed by Wahba (1997) and Amin (2007).

In most instances the actual cause of poisoning of $C$. perfringens is temperature abuse, small numbers of organisms are present, multiply to food poisoning levels during cool down and storage (Crouch and Golden, 2005).

So, two important points must be regarded to safe production of processed cheese, first one is the measures to minimize the presence of spores including low initial contamination levels in the feed and preventing their growth in the farm environment. The second is emphasizing the requirement for precautions that prevent spore germination and vegetative proliferation by adequate cooling during all steps of production till dispensation to the consumers.

\section{ACKNOWLEDGMENT}

The authors thanks Prof. Dr. S.S. El-Maraghy, Physiology of Fungi Lab., Fac. of Sci., Assiut Univ., for extraction, separation and bioassay of mycotoxins.

\section{REFERENCES}

A.P.H.A. (American Public Health Association) (1992): Compendium of Methods for the Microbiological examination of Foods. $2^{\text {nd }}$ Ed., American Public Health Association, Washington, DC, USA.

Abdel-Hameed, Z.M. (2004): Studies on Bacillus cereus and related species in heat treated milk and some milk products. M.V.Sc Thesis, Fac. Vet. Med., Assiut Univ.

Abdel-Malek, A.Y.; El-Maraghy, S.S. and Hasan, A.H. (1993): Mycotoxin producing potential isolates found in corn grains and sunflower seeds in Egypt. J. Islamic Academy of Science. 6: 189-192.

Ageitos, J.M.; Vallejo, J.A.; Sestelo, A.B.; Poza, M. and Villa, T.G. (2007): Purification and characterization of a milk clotting 
protease from Bacillus lichemiformis strain USC13. J. Appl. Microbiol. 103: 2205-2213.

Amin, W.F. (2007): Studies on market processed cheese products. Ph.D. Thesis, Fac. Vet. Med., Assiut Univ.

Beerens, H.; Romand, C.; Lepage, C. and Griquelion, J. (1982): A liquid medium for the enumeration of Clostridium perfringens in food and faeces. In: Isolation and Identification Methods for Food Poisoning Organisms. J. E. L. Corry; D. Roberts and F.A. Skinner (eds), Academic Press, London, pp.: 137-149.

Bennett, J.W. and Klich, M. (2003): Mycotoxins. Clin. Microbiol. Rev. 16: 497-516.

Borge, G.I.; Skeie, M.; Sorhaug, T.; Langsrud, T. and Granum, P.E. (2001): Growth and toxin profiles of Bacillus cereus isolated from different food sources. Int. J. Food Microbial. 69: 237246.

Bos, J.; Smithee, L.; McClane, B.; Distefano, R.F.; Uzal, F.; Songer, J.G.; Mallonee, S. and Crutcher, J.M. (2005): Fatal necrotizing colitis following a foodborne outbreak of enterotoxigenic Clostridium perfringens type A infection. Clin. Infect. Dis., 40: 78-83.

Carvajal, M.; Bolanos, A.; Rojo, F. and Mendez, I. (2003): Aflatoxin $\mathrm{M}_{1}$ in pasteurized and ultra pasteurized milk with different fat content in Mexico. J. Food Prot. 66: 1885-1892.

Cowan, S.T. and Steel, K.J. (1974): Manual for Identification of Medical Bacterial, $2^{\text {nd }}$ Ed., Cambridge, Cambridge Univ., Press.

Crouch, E. and Golden, N. (2005): A risk assessment for Clostridium perfringens in ready to eat and partially cooked meat and poultry products. USDA, Food Safety Inspection Service.

El-Maraghy, S.S. and Zohri, A.A. (1988): Mycotoxin producing potential of Aspergilli and Penicillia of broad beans in Egypt. Bull. Fac. Sci., Assiut Univ., 17: 91-102.

Eneroth, A.; Svensson, B.; Molin, G. and Christiansson, A. (2001): Contamination of pasteurized milk by B. cereus in the filling machine. J. Dairy Res., 68: 189-196.

Federico, L.; Francisco, F. and Martin, J.F. (2002): Production of penicillin by fungi growing on food products: Identification of a complete penicillin gene cluster in $\mathrm{P}$. griseofulvum and a 
truncated cluster in P. verrucosum. Appl. Environ. Microbiol. 68: 1211-1219.

Galle Le Bourhis, A.; Saunier, K.; Dore, J.; Carlier, J.; Chamba, J.; Robert Popoff, M. and Tholozan, J. (2005): Development and validation of PCR primers to assess the diversity of Clostridium spp. in cheese by temporal temperature gradient gel electrophoresis. Appl. Environ. Microbiol., 71: 29-38.

Ghelardi, E.; Celandroni, F.; Salvetti, S.; Barsotti, C.; Baggiani, A. and Senesi, S. (2002): Identification and characterization of toxigenic B. cereus isolates responsible for two food poisoning outbreaks. FEMS Microbiol. Lett., 208: 129-134.

Gimeno, A. (1979): Thin layer chromatographic determination of aflatoxins, ochratoxins, sterigmatocystin, Zeoralenone, Citrinin, T-2 toxin, diacetaxy scripenol, Penicillic acid, Patulin and Penitrem. J. AOAC, 62: 579-585.

Guinee, T.P. (2003): Pasteurized processed cheese products. In: Encyclopedia of Dairy Science, Vol. 1, Roginski, H.; Fuquay, J.W. and Fox, P.E. Eds. Academic Press, 411-418.

Hamed, A.; Khader, A.; Al-Khamy, A.F.; El-Garawany, G.A. and Abdel-Salam, M.H. (1997): Effect of storage on the composition, Rheological properties and organoleptic quality of commercial processed cheese. Egyptian J. Dairy Sci. 25: 113-122.

Hocking, A.D. and Faedo, M. (1992): Fungi causing thread mould spoilage of vaccum packaged cheddar cheese during maturation. Int. Dairy J. 16: 123.

Honikel, K.O. (2003): Man-made residues and environmental contaminants in meat. The $2^{\text {nd }}$ Int. Cong. of Food Hyg. and Human Health. Fac. Vet. Med., Assiut Univ., pp.: 54-63.

ICMSF (International Committee on Microbiological Specification for Foods) (1996): Bacillus cereus. In Microorganisms in Foods (Microbiological Specification of Food Pathogens). $1^{\text {st }} \mathrm{Ed}$. Blackie Academic \& Prof., London UK, pp.: 20-35.

Ismail, M.A. and Sabreen, M.S. (2001): Associated mycobiota of some types of cheese and cooking butter. Assiut Vet. Med. J. 44: 176-197.

Kalzendorf, C. (1995): Causes of high Clostridium spore counts in raw milk and measures for preventing spore transfer. Dentsche Milchwirstschaft. 46: 832-834. Dairy Sci. Abst. 58: 3211. 
Kisza, J. and Domagala, J. (1994): Aflatoxins in feed and milk: occurrence, assessment and methods of elimination. Medycyna of Weteryavyja. 50: 250-254.

Lancette, G.A. and Harmon, M. (1980): Enumeration and confirmation of Bacillus cereus in foods. J. Assoc. Off. Anal. Chem., 63: 581-586.

Leistner, L. and Gorris, L.G. (1995): Food preservation by hurdle technology. Trends Food Sci. Technol. 6:41-46.

Mansour, M.; Amir, D.; Bouttefroy, A.; Linder, M. and Milliere, J.B. (1999): Inhibition of B. licheniformis spore growth in milk by nisin, monolaurin and $\mathrm{pH}$ combinations. J. Appl. Microbiol., 86: 311-324.

Mountney, G. and Gould, W. (1988): Practical Food Microbiology and Technology. $3^{\text {rd }}$ Ed. An. Avi. Book Pub. New York.

Oxoid Manual (1990): Culture media, Ingredients and other Laboratory Services. $6^{\text {th }}$ Ed., Pub. Oxoid Ltd., London.

Peraica, M.; Radic, B.; Lucic, A. and Pavlovic, M. (1999): Toxic effects of mycotoxins in humans. Bull. World Health Org. 77: 754-766.

Pierides, M.; El-Nezami, H.; Peltonen, K.; Salminen, S. and Ahokas, J. (2000): Ability of dairy strains of lactic acid bacteria to bind Aflatoxins $\mathrm{M}_{1}$ in a food model. J. Food Prot. 63: 645-650.

Sabreen, M.S. and Zaky, Z.M. (2001): Incidence of aflatoxigenic molds and aflatoxins in cheeses. $1^{\text {st }}$ Cong. of Food Hygeine and Human Health. Fac. Vet. Med., Assiut Univ., pp.:241-257.

Sabry, Y.M. (2001): Thermoduric Psychrotrophic Bacteria in Milk and some Dairy products. M.V.Sc. Thesis, Fac. Vet. Med., Assiut Univ.

Salkinoja-Salonen, M.S.; Vuorio, R.; Anderson, M.A.; Kampfer, P.; Andrson, M.C.; Honkanen-Buzalski, T. and Scoging, A.C. (1999): Toxigenic strains of B. licheniformis related to food poisoning. Appl. Environ. Microbiol., 65: 4637-4645.

Sanz, J.C.; Dominguez, M.F.; Sagues, M.J.; Fernandez, M.; Feito, R.; Noguerales, R.; Asenio, A. and Fernandez Dela Hoz, K. (2002): Diagnosis and epidemiological investigation of an 
outbreak of Clostridium perfringens food poisoning. Enferm. Infec. Microbiol. Clin., 20: 117-122.

Sarimehmetoglu, B.; Kuplulu, O. and Halankcelik, T. (2004): Detection of aflatoxin $\mathrm{M}_{1}$ in cheese samples by ELISA. Food Control. 15: 45-49.

Scott, R.S.; Burger, H.G. and Quigg, H. (1980): A simple and rapid in vitro bioassay for inhibin. Endocrimol.107: 1536-1542.

Taniwaki, M. and Dender, A.G. (1992): Occurrence of toxigenic molds in Brazilian cheese. J. Food Prot. 55: 187.

Turnbull, P.C. (1997): The role of Bacillus cereus in infection. Culture. 18: 5-8.

Van Egmond, H.P.; Paulsch, W.E.; Deljill, E. and Schuller, P.L. (1980): Thin layer chromatographic method for analysis and chemical confirmation of sterigmatocystin in cheese. J. AOAC. 63: 110-114.

Vissers, M.M.; TeGiffel, M.C.; Driehuis, F.; De-Jong, P. and Lankveld, J.M. (2007): Minimizing the level of Bacillus cereus spores in farm tank milk. J. Dairy Sci., 90: 3286-3293.

Wafy, Y.M. (2006): Sanitary improvement of serving milk and dairy products in Assiut University Hospitals. Ph.D. Thesis, Fac. Vet. Med., Assiut Univ.

Wahba, Nahed M. (1997): Food poisoning spore forming microorganisms in milk and some milk products. M.V.Sc. Thesis, Fac. Vet. Med., Assiut Univ.

Yaroglu, T.; Orucand, H. and Tayar, M. (2005): Aflatoxin $\mathrm{M}_{1}$ levels in cheese samples from some provinces of Turkey. Food Control. 16: 883-885. 